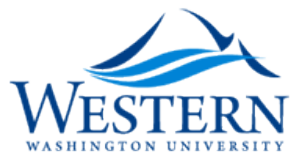

Western Washington University

Western CEDAR

1984

\title{
Interhabitat Differences in Energy Acquisition and Expenditure in a Lizard
}

Roger A. Anderson

Western Washington University, roger.anderson@wwu.edu

Follow this and additional works at: https://cedar.wwu.edu/biology_facpubs

Part of the Biology Commons

\section{Recommended Citation}

1984. Karasov, W.H. and R.A. Anderson. Interhabitat differences in energy acquisition and expenditure in a lizard. Ecology $65: 235-247$

This Article is brought to you for free and open access by the Biology at Western CEDAR. It has been accepted for inclusion in Biology Faculty and Staff Publications by an authorized administrator of Western CEDAR. For more information, please contact westerncedar@wwu.edu. 


\title{
INTERHABITAT DIFFERENCES IN ENERGY ACQUISITION AND EXPENDITURE IN A LIZARD ${ }^{1}$
}

\author{
William H. Karasov ${ }^{2}$ and Roger A. ANDERson \\ Department of Biology, University of California, Los Angeles, California 90024 USA
}

\begin{abstract}
Cnemidophorus hyperythrus, a small $(\approx 4-\mathrm{g})$ teiid lizard, occurs along an elevational thorn scrub-thorn woodland - thorn forest habitat gradient in the cape region of Baja California. We compared body size, daily energy expenditure (DEE, measured with doubly labeled water), relative feeding rate (as reflected by $\mathrm{H}_{2} \mathrm{O}$ influx rate), behavior, and abundance of this species at two sites along the gradient. At the inland thorn woodland site $C$. hyperythrus were more abundant $(\approx 100$ lizards/ha) than at the thorn scrub site near the ocean $(\approx 50$ lizards/ha). Mean body mass of woodland site lizards was $13 \%$ greater than that of scrub lizards. The DEE of the thorn woodland lizards, 330 $\mathrm{J} \cdot \mathrm{g}^{-1} \cdot \mathrm{d}^{-1}$, and their $\mathrm{H}_{2} \mathrm{O}$ influx, $99 \mathrm{~mm}^{3} \cdot \mathrm{g}^{-1} \cdot \mathrm{d}^{-1}$, were also higher than the thorn scrub lizards', 219 $\mathrm{J} \cdot \mathrm{g}^{-1} \cdot \mathrm{d}^{-1}$ and $52 \mathrm{~mm}^{3} \cdot \mathrm{g}^{-1} \cdot \mathrm{d}^{-1}$. Diets at the two sites were similar. There were no differences between sexes in diet, DEE, or $\mathrm{H}_{2} \mathrm{O}$ influx.

Daily maintenance energy costs were calculated based upon laboratory measures of $\mathrm{O}_{2}$ consumption of resting lizards at a series of temperatures that represented the daily range of body temperatures experienced by lizards in the field. Activity costs ( $=$ DEE minus maintenance) were three times higher in the woodland lizards. Behavioral observations showed that woodland lizards were active most of the day $(\approx 9 \mathrm{~h} / \mathrm{d})$ whereas scrub lizards were active primarily in the morning $(\approx 3.5 \mathrm{~h} / \mathrm{d})$. Thus, the higher activity cost, DEE, and feeding rate of woodland lizards can be explained by their longer daily activity period. We suggest causal factors for the difference in daily activity period, and discuss implications of length of daily foraging period for adult body size, population density, and various life history parameters of lizards.
\end{abstract}

Key words: Baja California; Cnemidophorus; daily activity period; daily energy expenditure; doubly labeled water; interhabltat variation; life history; lizard; thermoregulation; widely foraging; timeenergy budget.

\section{INTRODUCTION}

Energy acquisition and allocation provide a useful framework to study a range of ecological problems, from the consequences of animals' behaviors to life history phenomena. Within this framework, energy assimilation and energy metabolism are key processes because their rates set limits on the rate of production (or reproduction) which the individual animal, and the population in which it is a member, can achieve. During foraging the net rate of energy intake (intake minus expenditure) can vary with foraging tactic (Anderson and Karasov 1981), and for equal amounts of foraging time the animal with a higher rate of net energy intake will have more energy available to allocate for other behavioral activities and physiological processes. Alternatively, animals which forage for different amounts of time, but with similar rates of net energy intake, will have proportionally different amounts of energy available to allocate. Presumably, variation in clutch size, growth rate, body size, and other factors are effected through variation in these two important components of foraging: rate of net energy intake and amount of

\footnotetext{
1 Manuscript received 20 September 1982; revised 21 February 1983; accepted 14 March 1983.

2 Present address: Department of Physiology, School of Medicine, University of California, Los Angeles, California 90024 USA.
}

time spent foraging. Insofar as parameters of production and reproduction are assumed to be directly related to fitness, the importance of foraging time and energy balance during foraging is evident.

Both time available for foraging and food availability (which affects net energy intake) can vary spatially and temporally. For example, Mayhew (1966a, b), Vinegar (1975), Jameson and Allison (1976), Jameson (1980), Ballinger (1977, 1979, 1981), Martin (1977), Schoener and Schoener (1978), Vitt et al. (1978), Dunham (1978), Ballinger and Congdon (1980), and Stamps and Tanaka (1981) discuss the consequences of temporal (year-toyear) and/or spatial (geographic) differences in prey availability on growth rate, body size, and reproductive output in populations of lizards. Much of the emphasis in the study of lizard populations has been directed towards differences between allopatric populations or year-to-year variation within a population for the numerous parameters which relate to production and reproduction. However, variation in these parameters between habitats but within populations has been relatively uninvestigated. Developing an understanding of ecological differences between populations is difficult (Ferguson et al. 1980, Stearns 1980). In this regard, there are at least two special contributions which result from study of within-population interhabitat variation. First, interhabitat differences in parameters of production and reproduction (e.g., life history) may delineate 
greater extremes or different types of variation than are found in year-to-year population variation. Second, given that genotypic differences between populations may result in different distributions of phenotypes, known proximal causes of interhabitat phenotypic differences may be the same as the factors which result in ultimate genotypic differences.

In this study we compared key features of energy acquisition and expenditure in a lizard, Cnemidophorus hyperythrus, from two habitats along a habitat gradient in the cape region of Baja California. We used doubly labeled water (Lifson and McClintock 1966) to measure the energetic components of foraging, energy expenditure and relative feeding rate, and made behavioral observations relevant to the time component of foraging.

\section{METHODS \\ Study sites}

This study was performed in the arid tropical cape region (Wiggins 1980) of Baja California near Cabo San Lucas. This area is thorn scrub in the lower elevations, thorn woodland at intermediate, and thorn forest at higher elevations. Cnemidophorus hyperythrus is a small teiid lizard (native to most of Baja) found from sea level to at least $750 \mathrm{~m}$ at the cape. The region has relatively abundant late summer rainfall from midAugust to early October and less abundant and less predictable rainfall in mid-June to mid-August (Hastings 1969). Some of the deciduous perennial plant species break leaf bud dormancy in early July, while others begin later. The perennial vegetation has essentially full leaf expansion by early October. Annual plants become abundant by early October (Asplund 1967; W. H. Karasov and R. A. Anderson, personal observations).

We chose two sites along the habitat gradient. One site $(0.78 \mathrm{ha}), 9 \mathrm{~km}$ east of Cabo San Lucas along highway Mexico 1 , was in the thorn scrub vegetation $400 \mathrm{~m}$ from the Sea of Cortez at an elevation of $\approx 60$ $\mathrm{m}$. The second site (1.0 ha) was located in thorn woodland $9.1 \mathrm{~km}$ north of highway Mexico 1 on the road to Todos Santos (elevation $\approx 150 \mathrm{~m}$ ). These sites were $\approx 11 \mathrm{~km}$ apart on a direct line. The diurnal lizard communities at each site contained: Dipsosaurus dorsalis, Cnemidophorus hyperythrus and C. maximus, Callisaurus draconoides, Uta stansburiana, Sceloporus licki, and Urosaurus nigrocaudus. Ctenosaura hemilopha was also present at the woodland site.

An important difference between the two study sites was the physiognomy of the vegetation (Table 1). Total percent cover in a $15 \times 50 \mathrm{~m}$ belt transect (in the middle of each study area) was twice as great at the woodland site as at the scrub site. The number of litter patches and percent cover of litter, measured in five 50-m line transects, were both more than twice as large at the woodland site. The presence of trees and larger shrubs at the woodland site is reflected by the higher
TABLE 1. Plant and litter survey in two habitats near Cabo San Lucas, Baja California. Plants were surveyed in one $15-\times 50-\mathrm{m}$ belt transect and litter along five 50-m line transects. Values in parentheses are (SE, $N$ ).

\begin{tabular}{lcc}
\hline \hline & $\begin{array}{c}\text { Woodland } \\
\text { site }\end{array}$ & $\begin{array}{c}\text { Scrub } \\
\text { site }\end{array}$ \\
\hline Plants & 197 & 270 \\
Number of perennials & $309^{*}$ & 270 \\
Number of plants & 2627 & 3600 \\
Perennials/ha & $4120^{*}$ & 3600 \\
Plants/ha & 43.6 & 22.2 \\
Total \% cover, perennials & $48.5^{*}$ & 22.2 \\
Total \% cover, all plants & 16614 & 6155 \\
Mean cover per perennial (cm $\left.{ }^{2}\right)$ & 129 & 59 \\
Mean height, perennials (cm) & $(7,197)$ & $(2,223)$ \\
Mean height, all plants (cm) & 104 & 59 \\
& $(5,289)^{*}$ & $(2,223)$ \\
Number of common species & $>17 \dagger$ & $>9 \ddagger$ \\
Litter & & \\
Mean \% cover & 27 & 11 \\
Mean patch diameter (cm) & $(3,5)$ & $(3,5)$ \\
Mean number of patches per & 56 & 53 \\
transect & $(9,5)$ & $(10,5)$ \\
& $(3,5)$ & 10 \\
\hline
\end{tabular}

* Includes 112 individuals of large perennial geophyte Cnidosculus angustidens.

$\uparrow$ Species included: Cnidosculus angustidens, Mimosa xanti, Jatropha cinera, Bursera microphylla, Gossypium davidsonii, Croton caboensis, Melochia tomentosa, Lysiloma candida, Cyrtocarpa edulis.

$¥$ Species included: Jatropha cinera, Bursera hindsiana, Condaliopsis rigida, Indigofera fruticosa, Fouquieria diguettii, Antigonon leptopus, Opuntia.

mean perennial height and higher mean cover per perennial plant.

Cnemidophorus hyperythrus were reproducing at both sites during the study periods (30 August-17 September 1978, 7-17 September 1979). Autopsied females at both sites $(N=30)$ were at the stages of vitellogenic follicles, oviductal eggs, and corpora lutea, with no difference in the proportions at each stage between the two sites. Copulations were observed at both sites. However, none of our isotopically labeled females had large mass losses indicative of egg laying.

\section{Lizard behavior}

Lizards were noosed and deep-cloacal temperatures were measured with a Schultheis rapid-registering thermometer. Body temperature data were not used if animals fled prior to capture. Animals were toe-clipped, painted with an identification color, and later released at the point of capture.

Objectives of behavioral observations were to determine (1) the number of hours per day lizards at each site were active, and (2) the proportion of the daily activity period individual lizards at each site spent stationary and in movement.

Lizard activity (lizards seen per person-hour search- 
ing) was monitored in 1978 and 1979 by $1-3$ persons counting lizards while walking transects through each study area for $0.5-2 \mathrm{~h}$ during the morning (0900-1200) and afternoon (1200-1400). The only exception to this protocol was that in 1979 , lizard activity throughout the morning was estimated by measuring the amount of time it took to find each consecutive lizard. We then combined these search times into blocks of 1 personhour increments and expressed the data as number of lizards seen per person-hour searching. Time of first activity at each site was determined by checking at earlier hours (0630-0830).

Detailed behavioral observations were made in 1979. We watched $C$. hyperythrus individuals for $15 \mathrm{~min}$ each, recording seconds in locomotory behavior (walking, digging, climbing, scratching through leaf litter, etc.), approximate distances covered, number of bushes visited, prey capture bouts, and interactions with other lizards. The $C$. hyperythrus at both sites were observed with ease; individual lizards rarely appeared disturbed, and observation was terminated if a lizard displayed any sign of wariness.

\section{Lizard abundances}

We used the Lincoln Index (Peterson estimate) to compare C. hyperythrus population density at the two sites. This index calculates lizard number from the "dilution" of a known number of marked lizards by the unmarked subset of the population when marked and unmarked lizards are sampled simultaneously. We recorded the numbers of all lizards seen which were marked and unmarked during the aforementioned scheduled sampling periods and during other times working the plots. Daily Lincoln Indices $(L)$ were calculated as $L=(r \times n) /(m \times A)$ where $L=$ lizards per hectare, $r=$ total number of marked individuals, $n=$ total number of lizards seen during a sampling period, $m=$ number of marked lizards seen during a sampling period, and $A=$ area in hectares of the study plot. Since $m<10$ in every case, we also used the modified Lincoln Index for low recapture (resighting) sample size, $L^{\prime}=r(n+1) / A(m+1)$ (Caughley 1977, Begon 1979).

Caughley (1977) and Begon (1979) list several assumptions in using $L$, including (1) that all marks are retained through the sampling periods, (2) no deaths, births, emigrations, or immigrations occur, (3) capture and handling has no effect on subsequent resighting, and (4) sampling periods are short relative to lifespan. In our study, sampling of marked and unmarked animals occurred $\approx 1$ wk after painting and release of marked animals. We often checked all lizards sighted for toe clips and only once found a clipped lizard without paint; thus we concluded that the paint stayed on virtually all marked lizards. We have no death, emigration, or immigration data, but two points suggest to us that the magnitude of these phenomena was minimal. First, C. hyperythrus tended to have fidelity to a small home range. The mean distance between original capture point and subsequent resighting points $(N=$ 39 ) for these lizards was $11.4 \pm 1.2$ (SE) $\mathrm{m}$. No differences were observed in mean distance between sexes or sites. Second, we recaptured $42 \%$ of our labeled lizards in only 30 person-hours, and we are confident we could have recaptured more with additional time.

\section{Diet}

In 1979 males and females were captured at each site for identification of prey items in their stomachs. Lizards were captured in mid- or late morning to maximize the number of prey in the stomachs and to minimize digestive breakdown of the prey. Stomachs were removed and preserved in $70 \%$ ethanol. In the laboratory, arthropods were always identified to order, often to family. Many prey were swallowed whole, and when bodies were broken we counted only heads. Usually there was a 1:1 correspondence between heads and bodies.

\section{Water influx and field and laboratory energy expenditure}

Field metabolic rates and $\mathrm{H}_{2} \mathrm{O}$ influx rates were measured using the doubly labeled water method (Lifson and McClintock 1966). Congdon et al. (1978) and Nagy (1983a) validated this method for other lizards. The procedures we used are those described by Anderson and Karasov (1981).

Oxygen consumption (STP) of fed C. hyperythrus at different temperatures was measured in the laboratory by direct manometric technique with a single-valve Gilson Differential Respirometer. Lizards were captured at both sites in 1979 and returned to the University of California, Los Angeles where measures of $\mathrm{O}_{2}$ consumption were made between 26 September11 October. Lizards could have been postreproductive by then (no autopsies performed). Laboratory maintenance and resting metabolism measurement procedures have been described elsewhere (Anderson and Karasov 1981).

\section{Environmental temperatures}

Soil temperatures at 10,20 , and $40 \mathrm{~cm}$ depth were measured with a Yellow Springs Instruments thermistor thermometer over 24-h periods at each site. The probes were buried in locations which received sunlight filtered through branches of perennials. At least $12 \mathrm{~h}$ were allowed for thermal equilibration of the disturbed soil. Subsequently, temperatures were recorded at $2-\mathrm{h}$ intervals.

In 1978 and 1979 soil surface temperatures in sun and shade were measured hourly with a Schultheis rapid-registering reptile thermometer $\left(0^{\circ}-50^{\circ} \mathrm{C}\right)$. Soil surface temperatures $>50^{\circ}$ were measured with a standard $-10^{\circ}-100^{\circ}$ glass bulb mercury thermometer. Hourly measurements of air temperature were also made at 1 $\mathrm{cm}$ and $1 \mathrm{~m}$ above both shaded and unshaded soil surfaces. 
Numerical results are given as mean \pm standard error of the mean ( $n=$ number of measurements). The $t$ test $(P<.05)$ was used for tests of difference. When percentages were compared, they were transformed to arc$\sin \sqrt{p}$ values (Zar 1974) and the $t$ test was performed on the transformed values.

\section{RESULTS}

\section{Environmental conditions}

Most days $(n=12)$ during the 1978 labeled $\mathrm{H}_{2} \mathrm{O}$ study were clear and warm. On two occasions the morning sky was cloudy or hazy but cleared later. One day (3 September) was cloudy with intermittent sprinkles and occasional sun, but some $C$. hyperythrus were active.

Because plants were generally taller, broader, and more numerous at the woodland site (Table 1), a larger proportion of the ground was shaded throughout the day relative to the scrub site (Huey et al. 1977). Air temperatures measured at the same time were similar at the two sites (Fig. 1). Likewise, soil surface temperatures in the sun $\left(T_{s s}\right)$ were the same at the two sites.

\section{Behavior}

First sightings of $C$. hyperythrus in the morning occurred between 0800 and 0830 at both scrub and woodland sites in 1978. Although we did not formally monitor morning activity at the scrub site in 1978 , when capturing lizards to set up the labeling study the number captured per morning there ( 18 lizards) was similar to the number caught at the woodland site (12 lizards per morning) for an equivalent effort. Lizards were seen throughout the day at the woodland site up to $\approx 1800$. In contrast, $C$. hyperythrus activity almost completely ceased in the afternoon at the scrub site in 1978 (Table 2). Despite intensive searching efforts (16 person-hours) we found only six $C$. hyperythrus abroad in five afternoons at the scrub site. In contrast, there was no significant difference in number of lizards seen between morning and afternoon at the woodland site in 1978 (Table 2). Morning and afternoon lizard sightings for each site in 1979 cannot be directly compared because slightly different methods were used (see Methods). However, the data indicate that (as in 1978): (1) lizard activity was the same in the morning at the two sites, and (2) lizard activity in the afternoon was lower at the scrub site than at the woodland site. The greater lizard activity in the afternoon at the scrub site in 1979, relative to 1978 , was probably due to cooler temperatures as a result of recent rains. Based on lizard sightings, the daily activity period of $C$. hyperythrus at the scrub site during the 1978 study period was estimated to be $3.5 \mathrm{~h}$ (minimum estimate $3 \mathrm{~h}$, maximum $5 \mathrm{~h}$ ). At the woodland site, daily activity period was estimated to be $9 \mathrm{~h}$ (minimum $7 \mathrm{~h}$, maximum $10 \mathrm{~h}$ ).

At the woodland site, male $C$. hyperythrus spent significantly less of their activity period in locomotory behavior than did the syntopic females (Table 3). No

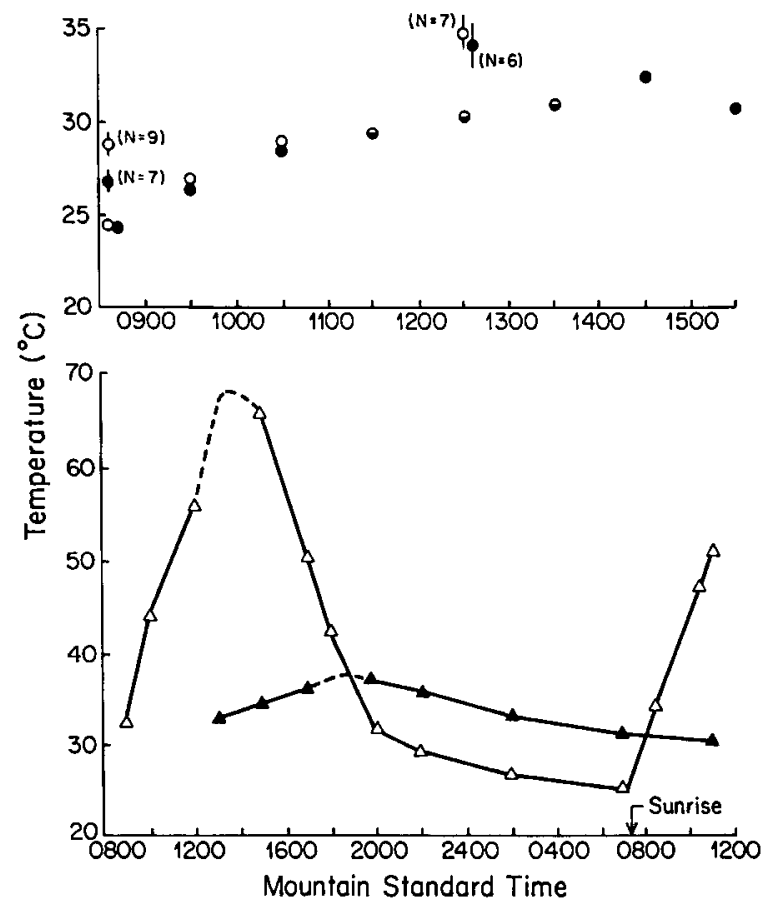

Fig. 1. Representative air and soil temperatures at study sites. Top figure shows daytime air temperatures at $1 \mathrm{~cm}$ above the soil surface in the shade at both sites on 12 September 1978 , and mean \pm SE for each site through the study period at 0830 and 1230 ( $N=$ number of days). O: scrub site, : woodland site. Lower figure shows temperature of soil surface exposed to full sunlight $\left(T_{s s}, \Delta\right)$ and temperature of soil at mean burrow depth $(10 \mathrm{~cm}, \Delta)$ at the scrub site on $16-$ 17 September 1978.

such differences between the sexes were detected at the scrub site nor did the data even suggest such a trend. Thus, except for males at the woodland site, C. hyperythrus spent $\approx 75 \%$ of their activity time in movement during this portion of the reproductive season.

When woodland site males were moving, they moved at a speed similar to the scrub site males (Table 3). At each site males covered more distance per unit locomotory time than did females (Table 3). Females generally moved slowly and appeared to investigate litter and the area under shrubs thoroughly while foraging. In contrast, males moved more rapidly both between and under plants, and often appeared to investigate litter and area under plants in a relatively cursory manner. These qualitative differences between males and females in foraging style during this reproductive season are reflected in the significantly higher number of perennial plants visited by males per minute of locomotion (Table 3 ). In addition to searching for prey, some males may have been patrolling their home range in search of females with which to initiate courtship. Similar differences in male and female foraging style during the reproductive season exist in $C$. $t$. tigris from the Colorado Desert of southern California, with the 
TABLE 2. Number of Cnemidophorus hyperythrus observed per person-hour searching time in the morning (0900-1200) and afternoon (1200-1400) at the two sites. Values are means for each day $\pm \mathrm{SE}, N=$ number of days, min = total searching time over all days. As described in Methods: Lizard behavior, values for 1979 morning at each site are means for blocks of time equivalent to one person-hour searching time. Sample sizes $(N)$ in this case indicate the number of blocks of time rather than the number of days. These observations occurred over $4 \mathrm{~d}$ at the woodland site and $3 \mathrm{~d}$ at the scrub site. Common superscripts within a row indicate significant differences between sites. Dash indicates absence of formal monitoring.

\begin{tabular}{|c|c|c|c|c|c|c|c|}
\hline \multirow[b]{2}{*}{ Year } & & \multicolumn{3}{|c|}{ Woodland site } & \multicolumn{3}{|c|}{ Scrub site } \\
\hline & & No. lizards & $N$ & $\min$ & No. lizards & $N$ & $\min$ \\
\hline 1978 & $\begin{array}{l}\text { Morning } \\
\text { Afternoon }\end{array}$ & $\begin{array}{r}5.8 \pm 0.6 \\
4.5 \dagger \pm 0.9\end{array}$ & $\begin{array}{l}4 \\
3\end{array}$ & $\begin{array}{l}915 \\
270\end{array}$ & $0.4+ \pm 0.1$ & 5 & 960 \\
\hline 1979 & $\begin{array}{l}\text { Morning } \\
\text { Afternoon }\end{array}$ & $\begin{array}{r}14 \pm 1.3 \\
8.6 \ddagger \pm 0.7\end{array}$ & $\begin{array}{l}4 \\
5\end{array}$ & $\begin{array}{l}176 \\
300\end{array}$ & $\begin{array}{c}13 \pm 3 \\
3.8 \neq \pm 0.8\end{array}$ & $\begin{array}{l}2 \\
5\end{array}$ & $\begin{array}{r}97 \\
300\end{array}$ \\
\hline
\end{tabular}

$\dagger=6.3, \mathrm{df}=6, P<.001$.

$\ddagger t=5.3, \mathrm{df}=8, P<.001$.

differences diminishing in the postreproductive season (R. A. Anderson, personal observation).

\section{Energy expenditure and water influx}

The mean body mass of Cnemidophorus hyperythrus at the woodland site was $13 \%$ greater than that at the scrub site (Table 4 ) and males at each site were $\approx 13 \%$ heavier than syntopic females $(t=2.3$, df $=54, P<$ $.05)$. Snout-vent length measurements in 1979 revealed that woodland males were significantly longer than scrub males, but there was no significant intersite difference in female lengths (Table 4). More than $75 \%$ of all lizard body mass changes were $< \pm 0.3 \mathrm{~g}$ over the 9 d capture-recapture interval. We cannot be sure that these changes in body mass were due only to changes in amount of body tissue rather than changes in stomach fill.

Mean body mass of $C$. hyperythrus used in laboratory measurements of resting $\mathrm{O}_{2}$ consumption $\left(\mathrm{V}_{2}\right)$ was $4.98 \mathrm{~g}$. Resting $\mathrm{VO}_{2}$ had a $\mathrm{Q}_{10}$ of 2.2 between $25^{\circ}$ and $35^{\circ} \mathrm{C}$ and 1.9 between $30^{\circ}$ and $40^{\circ}$ (Fig. 2). The energy equivalents of the resting rates (assuming 20.08 joules per cubic centimetre of oxygen; Schmidt-Nielsen 1975) were: $25^{\circ}, 3.1 \mathrm{~J} \cdot \mathrm{g}^{-1} \cdot \mathrm{h}^{-1} ; 30^{\circ}, 5.0 ; 35^{\circ}, 6.6 ; 40^{\circ}$, 9.6. There were no significant differences between sexes in $\dot{\mathrm{V}} \mathrm{O}_{2}$. We did not attempt a comparison of $\dot{\mathrm{VO}}_{2}$ of lizards from the two sites because our sample sizes were small. However, we obtained small variances in $\mathrm{VO}_{2}$ for pooled measurements on approximately equal numbers of lizards from both sites. This indicates to us that if there were any differences in resting $\mathrm{VO}_{2}$ between lizards at the sites, they were probably very small.

Mean $\mathrm{CO}_{2}$ production of free-living lizards at the thorn woodland site was $52 \%$ higher than at the scrub site (Table 4). At each site there was no significant difference in the mean $\mathrm{CO}_{2}$ production rates of males and females. The $\mathrm{CO}_{2}$ production rates are expressed per gram to correct partially for the differences in metabolic rate due to differences in body mass. On a wholeanimal basis (cubic centimetres per lizard per day) or a metabolic live mass basis $\left(\mathrm{cm}^{3} \cdot \mathrm{g}^{-0.8} \cdot \mathrm{d}^{-1}\right)$, thorn

TABLE 3. Percent of activity time spent moving and distance moved per unit moving time by Cnemidophorus hyperythrus observed between 0800-1230. Common superscripts within a row or column indicate significant differences.

\begin{tabular}{|c|c|c|c|c|c|c|c|}
\hline & \multirow[b]{2}{*}{ Sex } & \multicolumn{2}{|c|}{ Woodland site } & \multicolumn{2}{|c|}{ Scrub site } & \multicolumn{2}{|c|}{ Woodland + scrub } \\
\hline & & $\bar{x} \pm \mathrm{SE}$ & $\begin{array}{l}\text { No. liz- } \\
\text { ards }\end{array}$ & $\bar{x} \pm \mathrm{SE}$ & $\begin{array}{l}\text { No. liz- } \\
\text { ards }\end{array}$ & $\bar{x} \pm \mathrm{SE}$ & $\begin{array}{l}\text { No. liz- } \\
\text { ards }\end{array}$ \\
\hline $\begin{array}{l}\text { Percent of activity time in locomotory } \\
\text { activity }\end{array}$ & $\begin{array}{l}\delta \\
q\end{array}$ & $\begin{array}{l}56 \pm 6^{a, b} \\
76 \pm 6^{a}\end{array}$ & $\begin{array}{r}15 \\
8\end{array}$ & $\begin{array}{l}78 \pm 5^{b} \\
73 \pm 6\end{array}$ & $\begin{array}{l}8 \\
7\end{array}$ & & \\
\hline Distance per unit locomotion time $(\mathrm{m} / \mathrm{h})$ & 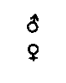 & $\begin{array}{r}165 \pm 19^{c} \\
59 \pm 15^{c}\end{array}$ & $\begin{array}{r}15 \\
8\end{array}$ & $\begin{array}{r}136 \pm 27 \\
73 \pm 43\end{array}$ & $\begin{array}{l}5 \\
3\end{array}$ & $\begin{array}{r}158 \pm 16^{d} \\
63 \pm 15^{d}\end{array}$ & $\begin{array}{l}20 \\
11\end{array}$ \\
\hline $\begin{array}{l}\text { Number of perennials visited per minute } \\
\text { locomotion time }\end{array}$ & $\hat{\imath}$ & $\begin{array}{l}1.3 \pm 0.1^{\mathrm{e}} \\
0.6 \pm 0.2^{\mathrm{e}}\end{array}$ & $\begin{array}{r}15 \\
8\end{array}$ & $\begin{array}{l}1.6 \pm 0.2 \\
0.8 \pm 0.3\end{array}$ & $\begin{array}{l}5 \\
5\end{array}$ & $\begin{array}{l}1.4 \pm 0.1^{f} \\
0.7 \pm 0.1^{f}\end{array}$ & $\begin{array}{l}20 \\
13\end{array}$ \\
\hline $\begin{array}{l}\text { Prey capture bouts observed (bouts per } \\
\text { hour of observation) }\end{array}$ & & $1.9 \pm 0.5$ & 24 & $2.7 \pm 1.0$ & 15 & & \\
\hline Observation time (min) & 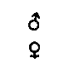 & $\begin{array}{l}211 \\
121\end{array}$ & & $\begin{array}{l}117 \\
120\end{array}$ & & & \\
\hline
\end{tabular}

$t$ test on $\arcsin \sqrt{p}, t=2.25, \mathrm{df}=21, P<.05$.

$t$ test on $\arcsin \sqrt{p}, t=2.49, \mathrm{df}=21, P<.025$.

c $t=3.79, \mathrm{df}=21, P<.005$. $\mathrm{d} t=5.3$, df $=29, P<.001$.

e $t=2.92, \mathrm{df}=21, P<.01$.

${ }^{\mathrm{f}} t=3.54, \mathrm{df}=31, P<.005$. 
TABLE 4. Body size, $\mathrm{CO}_{2}$ production, and water influx in free-living Cnemidophorus hyperythrus. Common superscripts indicate significant differences.

\begin{tabular}{|c|c|c|c|c|c|}
\hline & \multirow[b]{2}{*}{ Sex } & \multicolumn{2}{|c|}{ Woodland site } & \multicolumn{2}{|c|}{ Scrub site } \\
\hline & & $\bar{x} \pm \mathrm{SE}$ & $\begin{array}{l}\text { No. } \\
\text { lizards }\end{array}$ & $\bar{x} \pm \mathrm{SE}$ & $\begin{array}{l}\text { No. } \\
\text { lizards }\end{array}$ \\
\hline Body mass (g) & $\begin{array}{c}q \\
q \\
8+q\end{array}$ & $\begin{array}{l}4.6 \pm 0.2 \\
4.1 \pm 0.2 \\
4.4 \pm 0.2^{\mathrm{a}}\end{array}$ & $\begin{array}{l}18 \\
17 \\
35\end{array}$ & $\begin{array}{l}4.2 \pm 0.3 \\
3.6 \pm 0.1 \\
3.9 \pm 0.2^{\mathrm{a}}\end{array}$ & $\begin{array}{l}11 \\
10 \\
21\end{array}$ \\
\hline Changes in body mass $(\% / d)$ & $\begin{array}{l}\delta \\
q\end{array}$ & $\begin{array}{l}-0.9 \pm 0.3 \\
+0.1 \pm 0.4\end{array}$ & $\begin{array}{l}6 \\
6\end{array}$ & $\begin{array}{l}-0.6 \pm 0.3 \\
-0.3 \pm 0.3\end{array}$ & $\begin{array}{l}7 \\
4\end{array}$ \\
\hline Snout-vent length (mm) & $\begin{array}{c}\delta \\
\$ \\
\delta+q\end{array}$ & $\begin{array}{l}59 \pm 1^{b} \\
55 \pm 1 \\
56 \pm 1\end{array}$ & $\begin{array}{r}7 \\
13 \\
20\end{array}$ & $\begin{array}{l}54 \pm 2^{b} \\
55 \pm 1 \\
55 \pm 1\end{array}$ & $\begin{array}{r}9 \\
11 \\
20\end{array}$ \\
\hline $\mathrm{CO}_{2}$ production $\left(\mathrm{cm}^{3} \cdot \mathrm{g}^{-1} \cdot \mathrm{d}^{-1}\right)$ & $\begin{array}{l}q \\
q\end{array}$ & $\begin{array}{l}12.7 \pm 0.7^{\mathrm{c}} \\
13.2 \pm 1.1^{\mathrm{d}}\end{array}$ & $\begin{array}{l}6 \\
6\end{array}$ & $\begin{array}{l}8.8 \pm 1.2^{\mathrm{c}} \\
8.0 \pm 1.1^{\mathrm{d}}\end{array}$ & $\begin{array}{l}8 \\
4\end{array}$ \\
\hline Water influx $\left(\mathrm{mm}^{3} \cdot \mathrm{g}^{-1} \cdot \mathrm{d}^{-1}\right)$ & $\begin{array}{l}8 \\
q\end{array}$ & $\begin{array}{c}97 \pm 8^{e} \\
101 \pm 13^{i}\end{array}$ & $\begin{array}{l}6 \\
6\end{array}$ & $\begin{array}{l}53 \pm 6^{e} \\
49 \pm 9^{f}\end{array}$ & $\begin{array}{l}8 \\
4\end{array}$ \\
\hline $\begin{array}{l}{ }^{\mathrm{a}} t=2.11, \mathrm{df}=54, P<.05 \\
{ }^{\mathrm{b}} t=2.23, \mathrm{df}=14, P<.05 \\
{ }^{\mathrm{c}} t=2.44, \mathrm{df}=12, P<.05\end{array}$ & & $\begin{array}{l}{ }^{\mathrm{d}} t=3.0 \\
{ }^{\mathrm{e}} t=4.56 \\
{ }^{\mathrm{f}} t=2.58\end{array}$ & $\begin{array}{l}P<.0 \\
12, P< \\
8, P<.\end{array}$ & & \\
\hline
\end{tabular}

woodland lizards had significantly higher field $\mathrm{CO}_{2}$ production rates. The mean daily rates of $\mathrm{CO}_{2}$ production were converted to an energy equivalent called daily energy expenditure (DEE) expressed in joules per gram per day (Anderson and Karasov 1981). These rates were: woodland site $C$. hyperythrus, $330 \mathrm{~J} \cdot \mathrm{g}^{-1}$. $\mathrm{d}^{-1}$; scrub site, $219 \mathrm{~J} \cdot \mathrm{g}^{-1} \cdot \mathrm{d}^{-1}$.

The difference in DEE at the two sites was due primarily to a difference in expenditure due to activity. This is illustrated in Table 5. Daily cost of maintenance (resting metabolism) was calculated by integrating temperature-dependent rates of resting energy expenditure over the time-temperature cycle that lizards experienced at each site. We made the simplifying assumption that the lizards had body temperatures of $40^{\circ}$ during their activity period (Fig. 3). We assumed that for the remainder of the day (or all day in the "no activity" case) lizards rested at body temperatures equal to the soil temperature at burrow depth, $10.9 \pm 1.4 \mathrm{~cm}(n=$ 6 burrows) (Fig. 1). The difference between measured total energy expenditure and the calculated maintenance energy expenditure was taken as the expenditure of energy due largely to activity (daily activity cost). Woodland site lizards had higher daily maintenance costs due to a greater length of time at $40^{\circ}$ (lònger activity period) and much greater daily activity costs (Table 5).

Water influx rates were also higher at the woodland site (Table 4). There was no significant difference in $\mathrm{H}_{2} \mathrm{O}$ influx rate between the sexes at either site. Probably the lizards that spent more time active had higher DEE, which in turn increased their metabolic $\mathrm{H}_{2} \mathrm{O}$ production ( $\approx 10 \%$ of total $\mathrm{H}_{2} \mathrm{O}$ influx, see Discussion), and they captured more prey, which increased their food $\mathrm{H}_{2} \mathrm{O}$ intake. Most of the lizards had no access to drinking $\mathrm{H}_{2} \mathrm{O}$, and those woodland lizards labeled dur- ing the $1 \mathrm{~d}$ of light rain ( 3 September) had $\mathrm{H}_{2} \mathrm{O}$ influx rates not significantly different from woodland lizards labeled after the rain $(t=0.67, P>.5)$. Woodland site lizards labeled during the no-rain period (4-12 September) had a mean $\mathrm{H}_{2} \mathrm{O}$ influx $\left(93 \pm 10 \mathrm{~mm}^{3} \cdot \mathrm{g}^{-1}\right.$. $\mathrm{d}^{-1}, N=5$ ) significantly higher than that of the scrub lizards $(t=3.61$, $\mathrm{df}=15, P<.005)$. While drinking was not a factor in $C$. hyperythrus' $\mathrm{H}_{2} \mathrm{O}$ influx, we cannot rule out the possibility of $\mathrm{H}_{2} \mathrm{O}$ vapor influx. (The $\mathrm{H}_{2} \mathrm{O}$ vapor influx measured with labeled hydrogen results from the input, isotopic equilibration, and subsequent loss of externally supplied $\mathrm{H}_{2} \mathrm{O}$ vapor across the lungs and skin of animals [Nagy and Costa 1980].) Without knowing what proportion of total $\mathrm{H}_{2} \mathrm{O}$ influx is due to vapor, and the $\mathrm{H}_{2} \mathrm{O}$ content of prey, we cannot calculate absolute feeding rates from $\mathrm{H}_{2} \mathrm{O}$ influx data. However, we can make some qualitative comparisons of feeding rates.

\section{Diet analysis}

In order to use $\mathrm{H}_{2} \mathrm{O}$ influx rate as a relative measure of feeding rate, we needed to know if the diets (and thus $\mathrm{H}_{2} \mathrm{O}$ intake per gram of dry arthropod) were similar between sites and sexes. The proportions of arthropods from various orders in C. hyperythrus stomachs were generally similar between the sites (Fig. 4). At both sites $>80 \%$ of the entire number of prey in stomachs were from the same five orders (in decreasing order of importance): thorn scrub, Isoptera $>$ Araneida $>$ Thysanura $>$ coleopteran larvae $>$ Hymenoptera (mainly ants); thorn woodland, Isoptera $>$ coleopteran larvae $>$ Thysanura $>$ Araneida $=$ Homoptera (mainly treehopper) $>$ Hymenoptera. In most cases we think these orders were largely represented by only one or two species. Many of these prey are found in leaf litter and shallow soil. The 


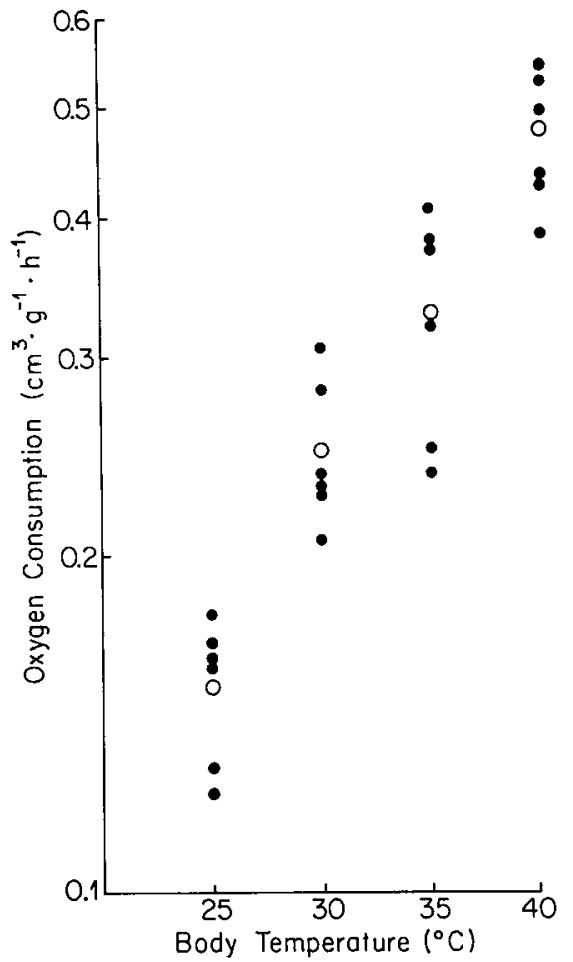

FIG. 2. Resting rate of oxygen consumption as a function of body temperature in fed Cnemidophorus hyperythrus. -: means for individual lizards (20 measurements per lizard) and $O$ : means for the six lizards.

only apparent difference between the sites in prey taken was that homopterans seemed more important for woodland site lizards and lepidopterans were more important for scrub site lizards. The proportion of each prey type captured by males and females was similar at both sites, except that females at the thorn woodland took more spiders and treehoppers than did males.

Because of differences in arthropod prey size, the most important prey items by number were not always the most important by biomass. For example, expressed in this manner (biomass $\cong$ volume $=$ prey length $\times$ prey diameter), isopterans were still the most important prey at the scrub site, but were fifth in importance at the woodland site. Overall, $80 \%$ of the prey by volume, and $90 \%$ of the prey by number, comprised the same six orders at both sites, and no single order represented $>20 \%$ of total prey by volume.

\section{Lizard abundance}

The estimate of $C$. hyperythrus per unit area at the thorn woodland site in 1978 was significantly higher than at the thorn scrub site (Table 6). In 1979 we attempted to mark a greater proportion of the lizards at each site by decreasing the plot size; we anticipated that this would increase the reliability of the estimates. Bad weather inhibited this effort, but about half the lizards at each plot were marked, and our calculations of numbers per unit area were remarkably similar to those in 1978 (Table 6). Thus, we did not detect a yearto-year difference in C. hyperythrus population density; results from both years indicate $C$. hyperythrus abundance was about two times higher in the thorn woodland than in the thorn scrub.

\section{DISCUSSION}

\section{Energy expenditure}

Resting metabolic rates of Cnemidophorus species (Asplund 1970, Bennett and Gleason 1979, Raglund et al. 1981, this study) are similar to those of iguanid lizards (Bennett and Dawson 1976) when corrected for differences in body mass. But the measured field metabolic rates (also mass-corrected) of free-living Cnemidophorus species (Anderson and Karasov 1981, this study) are clearly higher than those of iguanids. The field energy expenditure rates of C. hyperythrus, 288 and $444 \mathrm{~J} \cdot \mathrm{g}^{-0.8} \cdot \mathrm{d}^{-1}$, bracket the DEE of free-living, nonreproductive $C$. tigris in the Colorado Desert of California, $360 \mathrm{~J} \cdot \mathrm{g}^{-0.8} \cdot \mathrm{d}^{-1}$ (Anderson and Karasov 1981). The woodland site $C$. hyperythrus had the highest DEE rates reported among lizards (cf. Anderson and Karasov 1981, Nagy 1983b). The mean DEE for iguanid lizards is $224 \mathrm{~J} \cdot \mathrm{g}^{-0.8} \cdot \mathrm{d}^{-1}$ (Nagy $1983 b$ ).

Some obvious potential causes for differences in field energy expenditure between syntopic lizards are differences in: lengths of the activity and resting periods, temperature-dependent resting metabolic rates, body temperature during resting period $\left(=T_{\text {burrow }}\right)$ and while active, activity metabolism during the activity period, and reproductive state. We have shown elsewhere that the average rate of energy expenditure during the activity period of the widely foraging predator Cnemidophorus tigris was at least two times greater than that of a wait-and-ambush predator Callisaurus draconoides. Even though the 5-h activity period of Cnemi-

TABLE 5. A comparison of maintenance and activity energy expenditure in free-living Cnemidophorus hyperythrus at two sites and the predicted expenditure of a lizard remaining in a 10-cm deep burrow. Numbers within parentheses are estimates of minimum and maximum values. See text for explanation.

\begin{tabular}{|c|c|c|c|}
\hline & $\begin{array}{l}\text { Woodland } \\
\text { site }\end{array}$ & $\begin{array}{l}\text { Scrub } \\
\text { site }\end{array}$ & $\begin{array}{l}\text { No } \\
\text { activ- } \\
\text { ity }\end{array}$ \\
\hline$\overline{\text { Activity period (h/d) }}$ & $\begin{array}{c}9 \\
(7-10)\end{array}$ & $\begin{array}{r}3.5 \\
(3-5)\end{array}$ & 0 \\
\hline $\begin{array}{l}\text { Total daily energy } \\
\text { expenditure } \\
\left(\mathrm{J} \cdot \mathrm{g}^{-1} \cdot \mathrm{d}^{-1}\right)\end{array}$ & 330 & 219 & 151 \\
\hline $\begin{array}{l}\text { Daily maintenance cost } \\
\left(\mathrm{J} \cdot \mathrm{g}^{-1} \cdot \mathrm{d}^{-1}\right)\end{array}$ & $\begin{array}{c}181 \\
(169-184)\end{array}$ & $\begin{array}{c}166 \\
(164-171)\end{array}$ & 151 \\
\hline $\begin{array}{l}\text { Daily activity cost } \\
\left(\mathrm{J} \cdot \mathrm{g}^{-1} \cdot \mathrm{d}^{-1}\right)\end{array}$ & $\begin{array}{c}149 \\
(146-161)\end{array}$ & $\begin{array}{c}53 \\
(48-55)\end{array}$ & 0 \\
\hline
\end{tabular}




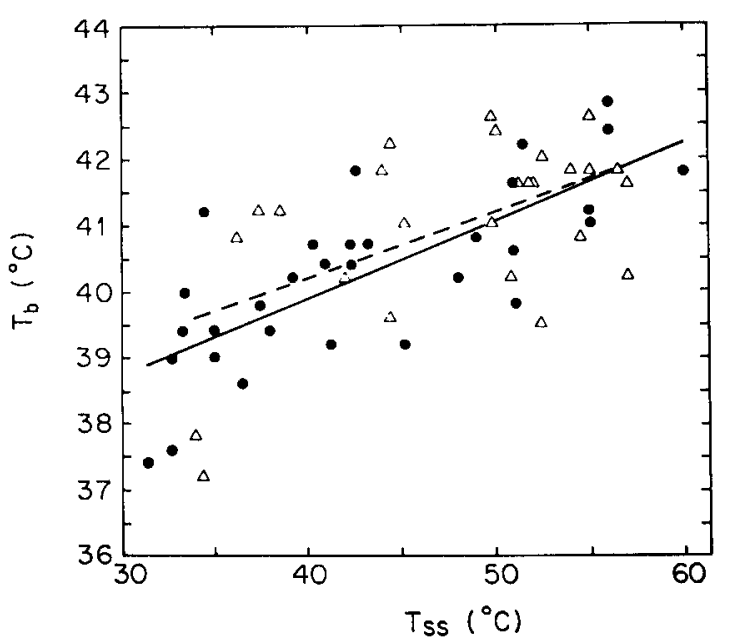

Fig. 3. Body temperatures $\left(T_{b}\right)$ of all Cnemidophorus hyperythrus captured during the activity period as a function of temperature of the soil surface exposed to full sunlight $\left(T_{s s}\right)$. Particular microenvironment and lizard behavior at time of capture varied. $\triangle,---$ : scrub site lizards; $, \longrightarrow, \longrightarrow$; woodland site lizards. There is no significant difference between the two lines (analysis of covariance) and the regression equation for the pooled data is $y=35.5+0.11 x(t=6.95, \mathrm{~d} f=55, P<$ $.001, r^{2}=0.47$ ).

dophorus tigris was half as long per day as Callisaurus draconoides', total DEE of Cnemidophorus tigris was $65 \%$ higher (Anderson and Karasov 1981). Our present study shows that when $C$. hyperythrus' activity period was even shorter $(\approx 3.5 \mathrm{~h} / \mathrm{d})$, its DEE was still higher than that of other iguanid lizards, including the syntopic Callisaurus draconoides near Cabo San Lucas (W. H. Karasov and R. A. Anderson, personal observation). Most of the difference in DEE between widely searching Cnemidophorus species and wait-and-ambush iguanids is due to differences in the energetic costs of their contrasting modes of predation.

A high metabolic rate during the activity period relative to the resting period metabolic rate causes the DEE to be sensitive to length of the activity period. Thorn woodland $C$. hyperythrus had estimated activity periods almost three times as long as thorn scrub lizards. As a result, thorn woodland lizards had daily activity costs almost three times higher and a total DEE $50 \%$ higher than the scrub site lizards (Table 5). Similarly, $C$. tigris in California had an activity period intermediate in length to that of $C$. hyperythrus at the scrub and woodland sites. Cnemidophorus tigris also had an intermediate mass-corrected activity cost and total DEE (Anderson and Karasov 1981). The importance of the activity cost as a component of total DEE is illustrated by the following calculation. A lizard simply resting in its burrow $24 \mathrm{~h} / \mathrm{d}$ would, theoretically, have a DEE of $151 \mathrm{~J} \cdot \mathrm{g}^{-1} \cdot \mathrm{d}^{-1}$. The cost of free-living at the woodland site would then be $330-151=179$
$\mathrm{J} \cdot \mathrm{g}^{-1} \cdot \mathrm{d}^{-1}$, of which $83 \%(149 / 179 \times 100)$ is accounted for by activity (Table 5 ). The remaining $17 \%$ is due to the effect of the higher $T_{b}$ of the lizard during activity on its rate of energy expenditure (Table 5).

Is it possible that scrtb site lizards had lower DEE because they were active fewer days than woodland site lizards? We think that the correspondence in the proportional difference between the two sites in both activity period length and activity cost (Table 5) argues against this. (It is important to note that because daily maintenance costs were almost independent of daily activity period length [Table 5], conclusions about differences in average daily activity cost are more or less independent of any assumption about whether individual lizards were active every day.) If individual lizards were not active every day, the data suggest that the number of days they were inactive must have been

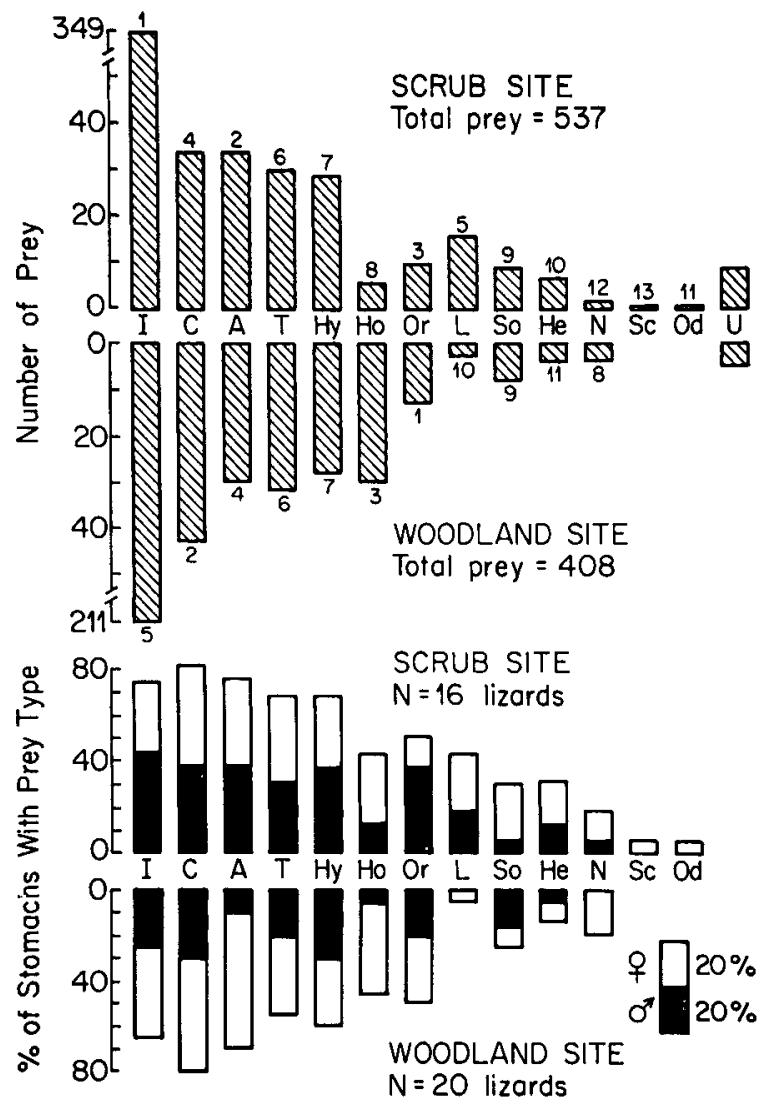

FIG. 4. Diet analysis of Cnemidophorus hyperythrus at the two sites. Top histograms represent total number of prey found in all stomachs, while numbers above the bars reflect the rank order of prey by volume. The lower histograms represent percent of all stomachs, according to sex, in which each order was found. Phylogenetic orders of arthropods are: Isoptera (I), Coleoptera (C), Araneida (A), Thysanura (T), Hymenoptera (Hy), Homoptera (Ho), Orthoptera (Or), Lepidoptera (L), Solpugida (So), Hemiptera (He), Neuroptera (N), Scorpionida $(\mathrm{Sc})$, Odonata (Od), and unclassified (U). 
TABLE 6. Proportions of observed Cnemidophorus hyperythrus which were marked and the calculated Lincoln Indices $(L)$ at the two sites. $L^{\prime}$ is the modified Lincoln Index for low recapture sample size. Common superscripts indicate $L$ values which are significantly different within a row or column.

\begin{tabular}{|c|c|c|c|c|c|c|}
\hline & \multicolumn{3}{|c|}{ Woodland site } & \multicolumn{3}{|c|}{ Scrub site } \\
\hline & $\bar{x} \pm \mathrm{SE}$ & $\begin{array}{l}\text { No. } \\
\text { days }\end{array}$ & $\begin{array}{l}\text { No. } \\
\text { lizards } \\
\text { seen }\end{array}$ & $\bar{x} \pm \mathrm{SE}$ & $\begin{array}{l}\text { No. } \\
\text { days }\end{array}$ & $\begin{array}{l}\text { No. } \\
\text { lizards } \\
\text { seen }\end{array}$ \\
\hline \multicolumn{7}{|l|}{1978} \\
\hline $\begin{array}{l}\text { Plot area (ha) } \\
\text { Number of marked lizards } \\
\text { Percent of observed lizards marked } \\
L \text { (number/ha) } \\
L^{\prime} \text { (number/ha) }\end{array}$ & $\begin{array}{l}1.1 \\
35 \\
26 \pm 3 \\
126 \pm 15^{\mathrm{a}} \\
115 \pm 13^{\mathrm{b}}\end{array}$ & $\begin{array}{l}4 \\
4 \\
4\end{array}$ & $\begin{array}{l}120 \\
120 \\
120\end{array}$ & $\begin{array}{l}0.78 \\
22 \\
65 \pm 11 \\
49 \pm 10^{a} \\
44 \pm 8^{b}\end{array}$ & $\begin{array}{l}5 \\
5 \\
5\end{array}$ & $\begin{array}{l}36 \\
36 \\
36\end{array}$ \\
\hline \multicolumn{7}{|l|}{1979} \\
\hline $\begin{array}{l}\text { Plot area (ha) } \\
\text { Number of marked lizards } \\
\text { Percent of observed lizards marked } \\
L \text { (number/ha) } \\
L^{\prime} \text { (number/ha) }\end{array}$ & $\begin{array}{r}0.25 \\
11 \\
42 \pm 2 \\
104 \pm 4 \\
93 \pm 4 \\
\end{array}$ & $\begin{array}{l}2 \\
2 \\
2 \\
\end{array}$ & $\begin{array}{l}19 \\
19 \\
19 \\
\end{array}$ & $\begin{array}{l}\quad 0.25 \\
\quad 9 \\
60 \pm 13 \\
60 \pm 12 \\
54 \pm 9\end{array}$ & $\begin{array}{l}2 \\
2 \\
2 \\
\end{array}$ & $\begin{array}{l}10 \\
10 \\
10 \\
\end{array}$ \\
\hline
\end{tabular}

a $t=4.5, \mathrm{df}=7, P<.005$.

${ }^{\mathrm{b}} t=4.9, \mathrm{df}=7, P<.005$.

the same at the two sites. Given that this was the peak of the reproductive season, it is plausible that most individuals were active every day. This was the case at least for Sceloporus virgatus males (Rose 1981) and for Callisaurus draconoides males and females (W. H. Karasov and R. A. Anderson, personal observation) during the reproductive season.

During the reproductive season, male and female $C$. hyperythrus differed in their behavior during the activity period. Males traveled twice as far and visited twice as many perennials per minute of locomotion time. In spite of these behavioral differences, male and female DEE were the same. However, the sexes were more similar in the proportion of time they spent in locomotion (Table 3 ). Perhaps what energy the females did not use in traveling they expended in scratching litter and digging in the soil. Also, doubly labeled water estimates of DEE, which are accurate to $\pm 10 \%$ (Nagy 1980 ), may not be sensitive to small energetic differences in the components of DEE.

We have not found a difference in DEE either in $C$. hyperythrus males and females, nor in C. tigris males and females (W. H. Karasov and R. A. Anderson, personal observation) during the reproductive season. When sex differences in DEE of reproductive lizards exist (cf. Nagy 1983a), presumably they are due to differences in time active, intensity of activity, or differences in standard metabolic rate while in the reproductive state. Future studies on reproductive energetics should focus on standard metabolic rates and field behavior as sources of differences in the DEE of males and females, in either reproductive or nonreproductive condition.

\section{Water influx and feeding behavior}

Insofar as the lizards could not or did not drink $\mathrm{H}_{2} \mathrm{O}$, their $\mathrm{H}_{2} \mathrm{O}$ influx was via three routes: (1) metabolic
$\mathrm{H}_{2} \mathrm{O}$ production, (2) preformed $\mathrm{H}_{2} \mathrm{O}$ in the food, and (3) $\mathrm{H}_{2} \mathrm{O}$ vapor. Metabolic $\mathrm{H}_{2} \mathrm{O}$ influx relative to metabolized energy can be estimated as $0.026 \mathrm{~mm}^{3} / \mathrm{J}$ (Schmidt-Nielsen 1975). Total influx minus metabolic $\mathrm{H}_{2} \mathrm{O}$ influx was $90 \mathrm{~mm}^{3} \cdot \mathrm{g}^{-1} \cdot \mathrm{d}^{-1}$ in woodland site lizards and $45 \mathrm{~mm}^{3} \cdot \mathrm{g}^{-1} \cdot \mathrm{d}^{-1}$ in scrub site lizards. While the possibility of vapor influx and our ignorance of the precise prey $\mathrm{H}_{2} \mathrm{O}$ content prohibit us from quantifying feeding rates, we can make some qualitative comparisons of feeding rates. For example, the similar $\mathrm{H}_{2} \mathrm{O}$ influx rates of males and females at each site, and the difference between the sites, can be interpreted as evidence that males and females at each site had similar feeding rates, and that feeding rates were higher at the woodland site. These conclusions result from the following considerations. First, based upon our observations, we can think of no substantive reason to suspect that males and females at each site had different vapor influxes. This is because within each site both sexes were almost certainly exposed to similar microenvironments and appeared to have similar activity-rest cycles. Second, since scrub lizards spent more time in burrows, which generally have higher absolute humidities than above-ground microenvironments, they would have higher vapor influxes than woodland lizards. Recall, however, that scrub lizards had lower total $\mathrm{H}_{2} \mathrm{O}$ influx rates. (Note that $\mathrm{H}_{2} \mathrm{O}$ vapor influx does not affect $\mathrm{CO}_{2}$ production measurements; Nagy 1980.) Third, since there was little difference in diet between sexes or sites, presumably the diet $\mathrm{H}_{2} \mathrm{O}$ content was similar among all groups. The two-times-higher $\mathrm{H}_{2} \mathrm{O}$ influx of the woodland lizards thus probably reflects their higher feeding rates $\left(=\left[\right.\right.$ total $\mathrm{H}_{2} \mathrm{O}$ influx metabolic - vapor]/food $\mathrm{H}_{2} \mathrm{O}$ content). Obversely, the similar $\mathrm{H}_{2} \mathrm{O}$ influx rates of males and females within each site reflect similar rates of feeding.

Interestingly, even with obvious differences in for- 
aging behavior, males and females still had similar feeding rates. Recall that males visited twice as many perennials per minute of locomotion time. How could males capture the same amount of food as females when they were apparently foraging less thoroughly under perennials than were females? By visiting more perennials, males may achieve the same capture rate by finding the rare arthropod near or on the surface beneath perennials or between perennials. Prey capture rates (capture bouts per hour of foraging) of males and females were not significantly different, and the pooled estimate of prey capture rate was about one capture bout per half-hour (Table 3). (This rate is an underestimate by at least one-half because [1] the mean number of prey per stomach, even excluding termites, was 11 per stomach, and these prey were collected over a mean time of $2.5 \mathrm{~h}$ of activity, and [2] we did not have each lizard's head in view for the entire observation period.) Based upon this low rate of prey capture it is not difficult to see how males could be as successful in foraging for the same prey as the apparently more thorough females.

Females may meet fewer visible prey at the surface than males, instead finding the greater proportion of these prey types by scratching through litter and digging in soil. The females may reduce risk of predation relative to males because they move into the open less often than males. Conversely, males may accrue a benefit worth the increased risk of predation: more opportunities for mating. Males may encounter more females per activity period by traveling greater distances than are typical for the females.

In light of this putative mate-seeking behavior it is intriguing that males at the woodland site spent a much greater proportion of their activity period sitting than did either the females at the woodland site or both sexes at the scrub site. It would seem that spending so much time sitting reduces the effectiveness of mateseeking rendered by high speeds while in movement. These disparate behaviors of woodland site males may have their basis in the greater population density of $C$. hyperythrus at the woodland site. The males may be assuming the role of wait-and-ambush mate-seekers. The number of females at the woodland site may be high enough to make waiting for females to pass by a viable mate-seeking mode for the woodland males. Maier and Waldbauer (1979) cite examples of dual mate-seeking strategies in male syrphid flies, which are similar to the dichotomy in thorn woodland male $C$. hyperythrus behavior. This switch-over from searching to waiting in some woodland site males would be comparable to the behavioral dichotomy in optimal foraging theory between wait-and-ambush and widely foraging predation (Schoener 1971, Tollestrup 1979, Huey and Pianka 1981, Toft 1981).

\section{Daily activity period}

As discussed above, the daily activity period of $C$. hyperythrus in the cape region of Baja California has a profound effect on their DEE and $\mathrm{H}_{2} \mathrm{O}$ influx. The factors which might account for a difference in the activity period of lizards at thorn woodland and thorn scrub sites merit some consideration. Is it advantageous for $C$. hyperythrus to be active as long as possible and, if so, why are thorn scrub lizards not active as long as the thorn woodland lizards?

It is likely that $C$. hyperythrus were not satiated for the day by morning feeding alone, since we saw thorn woodland lizards foraging, capturing, and eating prey in the afternoon. Furthermore, the higher water influx rates of the woodland lizards indicate they were eating more than scrub lizards, which fed primarily in the morning. Therefore, one reason the lizards at both sites may have been active as long as possible is that they appeared to be food limited given the available foraging time. Second, C. hyperythrus are not territorial, but, like other Cnemidophorus, forage with broadly overlapping home ranges (R. A. Anderson, personal observation. Bostic 1965, McCoy 1965). If mating success is related to the frequency of encounters with potential mates, then reproductive success may be increased for an individual lizard by having a longer activity period.

If it is advantageous to be active as long as possible during the late summer reproductive season, why are the thorn scrub $C$. hyperythrus less active than the thorn woodland lizards in the afternoon? Reduction or cessation of afternoon activity in various Cnemidophorus species has been associated with direct or indirect effects of high ambient temperatures in the summer afternoon (McCoy 1965, Milstead 1957, Echternacht 1967, Medica 1967, Tanner and Krogh 1974, Vitt and Ohmart 1977, Mitchell 1979, Anderson and Karasov 1981).

Asplund (1968) suggested a direct effect of temperature on C. tigris activity which takes into account the lizard's foraging behavior, plant physiognomy, and microclimate. In the afternoon small shrubs become unusable as foraging sites or thermoregulatory cooling sites because of incomplete shading of the substrate and resultant high shade temperatures $\left(>42^{\circ} \mathrm{C}\right)$ as the relative position of the sun changes (Huey et al. 1977). Coupled with high soil surface temperatures between shrubs ( $\approx 65^{\circ}$ in early afternoon), the thermal environment of $C$. tigris becomes too hot for the lizard to move between and forage under shrubs and simultaneously regulate its $T_{b}$ at $\approx 40^{\circ}$. Cnemidophorus tigris do move shrub to shrub, with foraging time at each shrub proportional to shrub size (R. A. Anderson, personal observation). Cnemidophorus hyperythrus foraged in a fashion similar to C. tigris. At the scrub site, plants are shorter and smaller in diameter, compared with the woodland site, and one might predict that the thermal problems for a foraging $C$. hyperythrus would become acute sooner. Also, as shown in Fig. 3, there is a direct correlation between $T_{s s}$ and mean body temperature $\left(T_{b}\right)$ of foraging $C$. hyperythrus. We interpret this changing $T_{b}$ in a lizard which probably has a temperature preferendum of $\approx 40^{\circ}$ (Asplund 1968, Bowker 
TABLe 7. Summary of differences between sites and their resident Cnemidophorus hyperythrus.

\begin{tabular}{lcr}
\hline \hline & $\begin{array}{c}\text { Thorn } \\
\text { scrub }\end{array}$ & $\begin{array}{r}\text { Thorn } \\
\text { wood- } \\
\text { land }\end{array}$ \\
\hline Vegetative cover $(\%)$ & 22 & 49 \\
Mean area per plant $\left(\mathrm{cm}^{2}\right)$ & 6200 & 16600 \\
Litter cover $(\%)$ & 11 & 27 \\
Lizard abundance $(\mathrm{number} / \mathrm{ha})$ & 50 & 100 \\
Daily activity period $(\mathrm{h} / \mathrm{d})$ & 3.5 & 9 \\
Daily energy expenditure & & \\
$\quad\left(\mathrm{J} \cdot \mathrm{g}^{-1} \cdot \mathrm{d}^{-1}\right)$ & 220 & 330 \\
Daily activity cost $\left(\mathrm{J} \cdot \mathrm{g}^{-1} \cdot \mathrm{d}^{-1}\right)$ & 53 & 149 \\
Water influx $\left(\mathrm{mm}^{3} \cdot \mathrm{g}^{-1} \cdot \mathrm{d}^{-1}\right)$ & 52 & 99 \\
Mean body mass $(\mathrm{g})$ & 3.9 & 4.4 \\
\hline
\end{tabular}

and Johnson 1980) to be a consequence of foraging widely in an environment where ambient temperatures are rising. As air and soil temperatures increase further, presumably foraging becomes incompatible with thermoregulating near $40^{\circ}$ and the lizards cease activity.

Vitt and Ohmart (1977) suggested that fossorial invertebrates may move deeper into the substrate as soil surface temperatures increase during the day. They gave the opinion that for $C$. tigris the energetic benefits of foraging did not outweigh the costs during the afternoon. This hypothesis assumes that there is a critical minimum arthropod abundance for widely foraging Cnemidophorus. The critical level may not be reached at all at the woodland site both because (1) a greater amount of shade-cooled soil there may result in a lower proportion of fossorial arthropods migrating deeper in the soil, out of reach of $C$. hyperythrus, and (2) the total arthropod abundance (possibly correlated with higher plant biomass) may be greater at the woodland site. Thus even if the same proportion of prey migrated as in the scrub site, the remaining available prey may still be greater than the critical minimum. However, isopterans may be the only fossorial prey of $C$. hyperythrus at our sites that are likely to migrate in such a manner, and they comprised, at most, only $20 \%$ of the biomass of the diet during our period of study.

Both direct and indirect thermal causes which effect reduced foraging activity of $C$. hyperythrus in early afternoon at the scrub site are plausible. We can imagine two other explanations for reduced afternoon activity in the scrub habitat. One might be higher predation risk at the thorn scrub site. A second possibility is that lower C. hyperythrus population density in the scrub habitat may result in fewer overlapping home ranges, and thus reduce the time necessary to encounter all neighbors that are potential mates. Therefore, there may not be the same incentive for scrub habitat $C$. hyperythrus to be active in the afternoon as there may be for the more densely populated woodland lizards. We do not have the necessary data to eliminate the nonthermal explanations. However, given the data at hand, we find the thermal explanations for reduced afternoon abundance of $C$. hyperythrus in the scrub site to have considerable merit. It seems significant that our frequency of sightings of $C$. hyperythrus in the scrub site in the afternoon relative to the morning was greater in the cooler afternoons during the 1979 study period that in the hotter afternoons of 1978.

\section{Synthesis}

The energetic and life history consequences of the length of the daily activity period for Cnemidophorus hyperythrus may be far-reaching. Let us assume that the capacity for growth is some function of both the time spent feeding and the difference between the rate of food intake and energy expenditure. Then, if the difference in activity period between the two sites exists throughout the hot season (at least $5 \mathrm{mo}$ ), differences in growth rate, and with it body mass (Table 4), might also be attributable to the difference in the length of the daily activity period. Difference in daily activity time between sites, accompanied by contrasts in feeding rate, generally have not been considered a possible cause of differences in rates of production (Ballinger et al. 1981). To speculate further, if high production rates are synonymous with high rates of reproduction and hatchling growth, perhaps differences in production rates could result in differences in lizard abundances as measured at the two sites. This appeared to be the case on the island of Abaco in the Caribbean; population densities of Anolis sagrei were higher at sites where lizards had higher individual growth rates (Schoener and Schoener 1978).

The intersite differences we have documented for $C$. hyperythrus body size, energetics, and behavior, and the postulated differences in growth rate, are of a sort that could be taken as evidence of genetically based differences. However, we have interpreted these phenotypic differences as proximate responses to two different environments. The distance between the study sites, $11 \mathrm{~km}$, in this vegetational gradient, may result in some genetic isolation between the sites. Hence we cannot absolutely rule out possible genetically based differences, but a genetic interpretation seems unnecessary. We think a more parsimonious explanation is the one we have given, based upon a single proximate factor: the length of the daily activity period.

There is a nascent and growing concensus that biologists studying life history phenomena of populations should consider proximate environmental sources of character variation before positing that phenotypic differences between populations have strong, differing genetic bases (Vitt et al. 1978, Ballinger 1979, Ferguson and Brockman 1980, Ferguson et al. 1980, Stearns 1980). For example, interhabitat differences (Schoener and Schoener 1978), seasonal differences (Stamps and Tanaka 1981, Merker and Nagy 1984), and year-toyear differences (both within and between generations) (Mayhew 1966a, b. Vinegar 1975, Ballinger 1977, 
Martin 1977, Dunham 1978, Vitt et al. 1978, Ballinger and Congdon 1980, Nagy 1983a) all contribute to character variation within and between populations.

In summary, the habitat gradient near Cabo San Lucas has associated with it changes in several aspects of $C$. hyperythrus biology (Table 7). These include the lizards' daily activity period, DEE, feeding rate, body size, and population density. Furthermore, the length of the daily activity period accounts directly for the differences in DEE and feeding rate and may even be responsible for the contrasts in body size and population density. Some obvious factors which require or allow an increased length of daily activity period are low prey abundance, time spent on behaviors associated with reproduction, high energy requirements for growth and reproduction, and equable microclimates. These factors may be opposed by those which require or allow a decreased length of daily activity such as limiting physical microclimate, increased predation pressure, high prey abundance, and reduced energy requirements. The energetic and life history consequences of the length of daily activity period for $C$. hyperythrus could be similarly manifested among many lizard species.

\section{ACKNOWLEDGMENTS}

This work was partially supported by National Research Service Award Training Grant GM 07191 to W. H. Karasov, and contract DE-AM03-76-SF00012 between the United States Department of Energy and the University of California (K. A. Nagy, principal investigator). Permission to collect lizards was granted by the Mexican government (Fauna Silvestre $87 / 906 / 79$ ). We are grateful to Corliss Karasov for help with field work, K. A. Nagy for laboratory facilities, and G. A. Bartholomew and J. M. Diamond for use of computers. We thank Drs. Royce Ballinger, Ray Huey, Ken Nagy, Philip Regal, and Laurie Vitt for their useful comments on the manuscript.

\section{Literature Cited}

Anderson, R. A., and W. H. Karasov. 1981. Contrasts in energy intake and expenditure in sit-and-wait and widely foraging lizards. Oecologia (Berlin) 49:67-72.

Asplund, K. K. 1967. Ecology of lizards in the relictual cape flora, Baja California. American Midland Naturalist 77: 462-475.

- 1968. Evolution of body size and habitat selection in whiptail lizards. Dissertation. University of California, Los Angeles, California, USA.

1970. Metabolic scope and body temperatures of whiptail lizards (Cnemidophorus). Herpetologica 26:403411.

Ballinger, R. E. 1977. Reproductive strategies: food availability as a source of proximal variation in a lizard. Ecology 58:628-635.

- 1979. Intraspecific variation in demography and life history of the lizard, Sceloporus jarrovi, along an altitudinal gradient in southeastern Arizona. Ecology 60:901-909.

- 1981. Food limiting effects in populations of Sceloporus jarrovi (Iguanidae). Southwestern Naturalist 25:554 557.

Ballinger, R. E., and J. D. Congdon. 1980. Food resource limitation of body growth rates in Sceloporus scalaris. Copeia 1980:921-923.

Ballinger, R. E., D. L. Droge, and S. M. Jones. 1981. Re- production in a Nebraska Sandhills population of the northern prairie lizard Sceloporus undulatus garmani. American Midland Naturalist 106:157-164.

Begon, M. 1979. Investigating animal abundance: capturerecapture for biologists. University Park Press, Baltimore, Maryland, USA.

Bennett, A. F., and W. R. Dawson. 1976. Metabolism. Pages 127-223 in C. Gans and W. R. Dawson, editors. Biology of the Reptilia. Volume 5. Academic Press, New York, New York, USA.

Bennett, A. F., and T. T. Gleason. 1979. Metabolic expenditure and the cost of foraging in the lizard Cnemidophorus murinus. Copeia 1979:573-577.

Bostic, D. L. 1965. Home range of the teiid lizard Cnemidophorus hyperythrus beldingi. Southwestern Naturalist 10: 278-281.

Bowker, R. G., and O. W. Johnson. 1980. Thermoregulatory precision in three species of whiptail lizards (LacertiliaTeiidae). Physiological Zoology 53:176-185.

Caughley, G. 1977. Analysis of vertebrate populations. John Wiley and Sons, London, England.

Congdon, J. D., N. W. King, and K. A. Nagy. 1978. Validation of the HTO-18 method for determination of $\mathrm{CO}_{2}$ production of lizards (genus Sceloporus). Copeia 1978:360362.

Dunham, A. E. 1978. Food availability as a proximate factor influencing individual growth rates in the iguanid lizard Sceloporus merriami. Ecology 59:770-778.

Echternacht, A. C. 1967. Ecological relationships of two species of the lizard genus Cnemidophorus in the Santa Rita Mountains of Arizona. American Midland Naturalist 78:448-459.

Ferguson, G. W., C. H. Bohlen, and H. P. Woolley. 1980. Sceloporus undulatus: comparative life history and regulation of a Kansas population. Ecology 61:313-322.

Ferguson, G. W., and T. Brockman. 1980. Geographic differences of growth rate of Sceloporus lizards (Sauria: Iguanidae). Copeia 1980:259-264.

Hastings, J. R. 1969. Climatological data and statistics for Baja California. Technical reports on the meteorology and climatology of arid regions, Number 18. Institute of Atmospheric Physics, University of Arizona, Tucson, Arizona, USA.

Huey, R. B., and E. R. Pianka. 1981. Ecological consequences of foraging mode. Ecology 62:991-999.

Huey, R. B., E. R. Pianka, and J. A. Hoffman. 1977. Seasonal variation in thermoregulatory behavior and body temperature of diumal Kalahari lizards. Ecology 58:10661075.

Jameson, E. W., Jr., and A. Allison. 1976. Fat and breeding cycles in two montane populations of Sceloporus occidentalis (Reptilia, Lacertilia, Iguanidae). Journal of Herpetology 10:210-220.

Jameson, E. W., Jr., A. A. Heusner, and D. Lem. 1980. Seasonal, sexual and altitudinal variations in stomach contents and ingested fat in Sceloporus occidentalis. Journal of Herpetology 14:255-261.

Lifson, N., and R. McClintock. 1966. Theory of use of the turnover rates of body water for measuring energy and material balance. Journal of Theoretical Biology 12:46-74.

Maier, C. T., and G. P. Waldbauer. 1979. Dual mate-seeking strategies in male syrphid flies (Diptera: Syrphidae). Annals of the Entomological Society of America 72:54-61.

Martin, R. G. 1977. Variation in reproductive productivity of range margin tree lizards (Urosaurus ornatus). Copeia 1977:83-92.

Mayhew, W. W. 1966a. Reproduction in the arenicolous lizard Uma notata. Ecology 47:9-18.

. 1966b. Reproduction in the psammophilous lizard Uma scoparia. Copeia 1966:114-122.

McCoy, C. J. 1965. Life history and ecology of Cnemi- 
dophorus tigris septentrionalis. Dissertation. University of Colorado, Boulder, Colorado, USA.

Medica, P. A. 1967. Food habits, habitat preference, reproduction, and diurnal activity in four sympatric species of whiptail lizards (Cnemidophorus) in south central New Mexico. Bulletin of the Southern California Academy of Sciences 66:251-276.

Merker, G. P., and K. A. Nagy. 1984. Energy utilization by free-ranging Sceloporus virgatus lizards. Ecology 65.

Milstead, W. W. 1957. Observations on the natural history of four species of whiptail lizard, Cnemidophorus (Sauria, Teiidae) in Trans-Pecos Texas. Southwestern Naturalist 2: 105-121.

Mitchell, J. C. 1979. Ecology of southeastern Arizona whiptail lizards (Cnemidophorus: Teiidae): population densities, resource partitioning and niche overlap. Canadian Journal of Zoology 57:1487-1499.

Nagy, K. A. 1980 . $\mathrm{CO}_{2}$ production in animals: analysis of potential errors in the doubly labeled water method. American Journal of Physiology 238:R466-R473.

1983a. Ecological energetics of a lizard. Pages 2454 in R. B. Huey, E. R. Pianka, and T. W. Schoener, editors. Lizard ecology: studies of a model organism. Harvard University Press, Cambridge, Massachusetts, USA.

- $1983 \mathrm{~b}$. Energy requirements of free-living iguanid lizards. Pages 49-59 in G. M. Burghardt and A. S. Rand, editors. Iguanas of the world: behavior, ecology and evolution. Garland STPM Press, New York, New York, USA.

Nagy, K. A., and D. P. Costa. 1980. Water flux in animals: analysis of potential errors in the tritiated water method. American Journal of Physiology 238:R454-R465.

Raglund, I. M., L. C. Wit, and J. C. Sellers. 1981. Temperature acclimation in the lizards Cnemidophorus sexlineatus and Anolis carolinensis. Comparative Biochemistry and Physiology 70A:22-26.

Rose, B. 1981. Factors affecting activity in Sceloporus virgatus. Ecology 62:706-716.
Schmidt-Nielsen, K. 1975. Animal physiology. Cambridge University Press, New York, New York, USA.

Schoener, T. W. 1971. Theory of feeding strategies. Annual Review of Ecology and Systematics 2:369-404.

Schoener, T. W., and A. Schoener. 1978. Estimating and interpreting body-size growth in some Anolis lizards. Copeia 1978:390-405.

Stamps, J., and S. Tanaka. 1981. The influence of food and water on growth rates in a tropical lizard Anolis aeneus. Ecology 62:33-40.

Stearns, S. C. 1980. A new view of life history evolution. Oikos 35:266-281.

Tanner, W. W., and J. E. Krogh. 1974. Variations in activity as seen in four sympatric lizard species of southern Nevada. Herpetologica 30:303-308.

Toft, C. A. 1981. Feeding ecology of Panamanian litter anurans: patterns in diet and foraging mode. Journal of Herpetology 15:139-144.

Tollestrup, K. 1979. The ecology, social structure, and foraging behavior of two closely related species of leopard lizards, Gambelia silus and Gambelia wislizenii. Dissertation. University of California, Berkeley, California, USA.

Vinegar, M. B. 1975. Demography of the striped plateau lizard, Sceloporus virgatus. Ecology 56:172-182.

Vitt, L. J., and R. D. Ohmart. 1977. Ecology and reproduction of Lower Colorado River lizards: II. Cnemidophorus tigris (Teiidae) with comparisons. Herpetologica 33: 223-234.

Vitt, L. J., R. C. Van Loben Sels, and R. D. Ohmart. 1978. Lizard reproduction: annual variation and environmental correlates in the iguanid lizard Urosaurus graciosus. Herpetologica 34:241-253.

Wiggins, I. L. 1980. Flora of Baja California. Stanford University Press, Stanford, California, USA.

Zar, J. H. 1974. Biostatistical analysis. Prentice-Hall, Englewood Cliffs, New Jersey, USA. 